\title{
Tuotanto-olojen mittaus kotieläinrakennuksissa: mitä, miten ja miksi
}

Mikko Hautala ja Jukka Ahokas

Agroteknologian laitos, Helsingin yliopisto

\section{Tiivistelmä}

Eläinsuojan sisäilman tulee olla sellainen, että eläin, ihminen ja rakennus voivat hyvin. Se tarkoittaa sopivaa lämpötilaa, ilman kosteutta ja riittävän alhaisia kaasu-, mikrobi ja pölypitoisuuksia. Tutkimuksiemme tavoitteena on luoda yleiset fysikaalis-kemialliset mallit karjasuojien ilmanvaihdolle ja lämpötilalle suojan mikroilmastoon (lämpötila, kosteus, kaasut, pöly, mikrobit, home) sekä eläinten lämpötasapainoon vaikuttavien tekijöiden funktiona. Tutkimuksissa kehitettävien mallien antama optimaalinen ilmasto saadaan aikaan oikealla ilmanvaihdolla. Tarvitaan automatisoitu tai hälytyksiä antava järjestelmä, jonka avulla karjasuojan optimiolosuhteet voidaan toteuttaa mahdollisimman stabiililla tavalla. Tarkoitusta varten tarvitaan puolestaan oikeita asioita mittaavat kohtuuhintaiset ja luotettavat anturit. Anturien tuloksia voidaan siis käyttää ilmanvaihdon säätöön, jolloin vain yhden suureen säädöstä (lämpötila tai kosteus tai hiilidioksidi tai muu kaasu) voidaan siirtyä mallintamissäätöön, jossa voidaan käyttää useampaa suuretta samanaikaisesti ja sillä tavoin parantaa karjasuojien sisäilman laatua. Optimoimalla niin karjasuojien kuin siellä oleilevien eläinten ja ihmisten terveys voidaan vaikuttaa ratkaisevasti tilan hoidon kustannuksiin ja edelleen hyvinvoinnin kautta tuotantoon ja tuotannon laatuun.

Rajat eläimen hengitysilman kaasuille ovat suuruusluokaltaan samoja kuin ihmisille annetut rajat. Varsinkin talvella kaasupitoisuudet ovat korkeita, koska karjanhoitaja pyrkii säätämään ilmanvaihdon sellaiseksi (=niin pieneksi), että lämpötila on karjanhoitajalle siedettävä. Mittauksissamme kävi ilmi, että vaikka hiilidioksidipitoisuus oli alle säädetyn rajan $(3000 \mathrm{ppm})$, samaan aikaan ammoniakkipitoisuus ylitti sallitun rajan. Pölyn määrä karjasuojassa on huomattavasti korkeampi kuin ihmisasumuksissa, ja sitä lisää myös turpeen ja olkien käyttö makuupaikan kuivikkeena. Liian korkea lämpötila yhdessä ilman kosteuden kanssa aiheuttaa helposti rakenteiden ja rehun homehtumista ja lisää homeitiöiden määrää ilmassa.

Helsingin yliopiston Agroteknologian laitokselle on viime vuosina hankittu kattava mittauslaitteisto karjasuojien mikroilmaston sekä eläinten, työntekijöiden ja rakennusten hyvinvointiin liittyvien fysikaalisten parametrien mittaamiseksi. Kannettavalla kaasuspektrometrilla on mahdollista mitata lähes kaikkia navetan kaasuja. Pöly- ja mikrobimittauksia varten on omat laitteensa. Jatkuvaan ammoniakin mittaamiseen soveltuvia antureita on testattu useita vaihtoehtoja. Kosteus-, hiilidioksidija lämpötilamittauksia varten on rakennettu omat anturoinnit, jonka etuna on kaupallisia versioita edullisempi hinta, jolloin antureiden lukumäärää mittauksissa voidaan kasvattaa. Runsaslukuisina hiilidioksidi- (tai muu kaasu), lämpötila- ja kosteusanturit mahdollistavat navetan mikroilmaston täydellisen avaruudellisen kartoittamisen. Anturit on kytketty tiedonkeruulaitteistoon, joka lähettää mittaustulokset automaattisesti verkkosivulle (on line) mistä tahansa karjasuojasta Suomessa GSMverkon kautta tietokantapalvelimelle. Lämpökamera mahdollistaa eläimen säteilylämpötilajakauman mittaamisen. Lämpökameralla on helppo paikallistaa eläimen kriittiset alueet kuten korvat, utareet tai häntä. Esityksessä esitellään käynnissä olevia mittauksia ja saatuja tuloksia. Tässä esityksessä esitellään automaattisia mittausmenetelmiä ja saatuja tuloksia.

Asiasanat: eläinsuoja, sisäilmasto, mittaus 


\section{Johdanto}

Ilmanvaihdon, kaasun tai lämmöntuoton ja täysin sekoitetun sisäilman välillä on taseyhtälöstä saatava yhteys, joka pätee tasapainotilanteessa eli kun mikään muuttuja ei ole ajan funktio:

$\operatorname{tuotto}\left(\mathrm{m}^{3} / \mathrm{s}\right)=$ ilmanvaihto*(cin-cout) tai tuotto $(\mathrm{W})=$ ilmanvaihto*tiheys*c*(Tin-Tout)

Ilmanvaihto saadaan lasketuksi näistä yhtälöistä, kun tuotot tunnetaan, ja sisäilman tavoitearvot cin ja Tin on määritelty.

Maatalouden tuotantorakennusten lämpöhuollosta ja huoneilmastosta on olemassa MMM:n ohje (MMM-RMO C2.2, 2002), jossa on suosituksia ja raja-arvoja lämpötiloille, kaasuille ja ilmanvaihdolle. On huomion arvoista, että suositusten rajat ovat erilaisia eri maissa esimerkkeinä Suomen edellä mainittu suositusraportti ja vastaava CIGR:n suositus. Eläinkohtaisten suositusten pitäisi olla samanlaiset, koska kyse on eläimen hyvinvoinnista, ja esimerkiksi ilmasto-olosuhteilla ei ole vaikutusta raja-arvoihin vaikka sillä onkin suuri merkitys karjasuojien laatuun ja olosuhteisiin suojissa. Raja-arvoihin vaikuttaa eläinrotu eikä kaikille roduille voidakaan käyttää samoja raja-arvoja. Esimerkiksi ylämaankarjan kaltainen karvapeite sallii huomattavasti kylmemmät olosuhteet. Samoin tuotanto vaikuttaa eläimen kylmänsietokykyyn, ja esimerkiksi lypsy- ja liharotuiset lehmät selviytyvät erilailla kylmässä. Nykyiset suositukset eivät välttämättä ota oikealla tavalla huomioon muun muassa lisääntyneen maidontuotannon aiheuttamaa lämmöntuoton kasvua: C2.2. raportti olettaa lehmän lämmöntuotoksi $700 \mathrm{~W}$, kun todellisuudessa hyvätuottoinen lehmä tuottaa ainakin $1000 \mathrm{~W}$. Lisäongelman lämmön tai vilun tuntemukseen tuovat itse suojan lämpötilan lisäksi ilman ja makuupaikan kosteus ja lämpötila sekä tuulen määrä.

Rajat eläimen hengitysilman kaasuille ovat suuruusluokaltaan samoja kuin ihmisille annetut rajat. Sitä, minkä kaasujen pitoisuudet hengitysilmassa ovat käytännössä muita ratkaisevampia, ei ole juurikaan tutkittu. Varsinkin talvella kaasupitoisuudet ovat korkeita, koska karjanhoitaja pyrkii säätämään ilmanvaihdon sellaiseksi (=niin pieneksi), että lämpötila on karjanhoitajalle siedettävä. Mittauksissamme kävi ilmi, että vaikka hiilidioksidipitoisuus oli alle säädetyn rajan (3000 ppm), samaan aikaan ammoniakkipitoisuus ylitti sallitun rajan. Pölyn määrä karjasuojassa on huomattavasti korkeampi kuin ihmisasumuksissa, ja sitä lisää myös turpeen ja olkien käyttö makuupaikan kuivikkeena. Turve toisaalta on alustavien mittaustulosten mukaan kaasupitoisuuksien vähentäjä osin sen takia, että se alentaa lannan pH-arvoa, mutta toisaalta myös sen takia, että se vaikeuttaa kaasujen haihtumista, kun turpeessa oleva ilmakerros ei liiku.

Karjasuojalla itsessään on myös vaikutusta niin eläinten kuin suojassa työskentelevien ihmisten hyvinvointiin. Liian korkea lämpötila yhdessä ilman kosteuden kanssa aiheuttaa helposti rakenteiden ja rehun homehtumista ja lisää homeitiöiden määrää ilmassa. Lisäksi karjasuojalle tyypillisten kaasujen, lähinnä hiilidioksidin, ammoniakin ja metaanin, pitoisuudet ovat hyvin erilaisia riippuen suojan rakenteesta. Niin hiukkas- kuin kaasupitoisuudet vaihtelevat myös hyvin merkittävästi eri kohdissa karjasuojaa ja riippuvat lisäksi myös tuuletuksesta mukaan lukien ilmavirtaukset ja niiden suunnat. Tällä on merkitystä varsinkin suojissa, missä eläimet pääsevät vapaasti liikkumaan ja makaamaan.

Optimoimalla niin karjasuojien kuin siellä oleilevien eläinten ja ihmisten terveys voidaan vaikuttaa ratkaisevasti tilan hoidon kustannuksiin ja edelleen hyvinvoinnin kautta tuotantoon ja tuotannon laatuun. Tutkimuksen tulosten avulla voidaan luoda suositusjärjestelmä, joka ottaa huomioon hyvinvointiin liittyvät mikroilmastotekijät samanaikaisesti. Tämä helpottaa tilojen valvontaa ja edesauttaa kattavan automatiikan kehittämistä tiloille.

Hanke on jatkoa tutkimuskonsortion (Helsingin yliopiston Agroteknologian laitos ja Tarton maatalousyliopisto) aiemmille tutkimuksille, joissa on kehitetty eläinten käyttäytymisen ja hyvinvoinnin mittausmenetelmiä (1-20) sekä mitattu usean vuoden ajan navetoiden mikroilmastoa ja kaasupitoisuuksia niin Suomessa kuin Virossa eri tyyppisissä navetoissa (21-30).

Mittaustulosten selittämiseksi kehitettiin päästölaskentaa varten uusi pihatoiden luonnollisen ilmanvaihdon mittaustapa (21) sekä luotiin fysiikkaan ja kemiaan perustuva ammoniakkipäästömalli $(23,28)$. Luonnollisen ilmanvaihdon mittaaminen ei onnistu tavanomaisilla menetelmillä, koska ilman virtaukset eivät ole samalla lailla yksiselitteisiä kuin koneellisessa ilmanvaihdossa. Ammoniakkipäästöille kehitetyn mallin mukaan päästöt riippuvat lähinnä lannan lämpötilasta ja 
happamuudesta eli pH-arvosta. Ammoniakkiemissio eli ammoniakin siirtyminen lannasta ympäristöön (grammaa) tunnissa pinta-alayksikköä kohti on $(23,28)$

$$
\operatorname{emissio}\left(\mathrm{g} / \mathrm{m}^{2} / \mathrm{h}\right) \approx 0.02 \cdot 10^{\left.T{ }^{\circ} \mathrm{C}\right) / 20+p H-8} \cdot C_{T A N}\left(\mathrm{~kg} / \mathrm{m}^{3}\right) / \delta(\mathrm{mm})
$$

Mallissa $\mathrm{T}$ on lannan pintalämpötila, $\mathrm{pH}$ on lannan pinnan happamuusaste, $\mathrm{C}_{\mathrm{TAN}}$ on kokonaisammoniakkipitoisuus lannassa ja $\delta$ on lannan pinnalla olevan rajakerroksen paksuus, jonka läpi kaasumolekyylit joutuvat diffundoitumaan. Kaavan (1) mukaan esimerkiksi $20{ }^{\circ} \mathrm{C}: n$ muutos lämpötilassa tai $\mathrm{pH}: n$ alentaminen yhdellä yksiköllä vähentää emission kymmenenteen osaan. Kokonaisemissio on suoraan verrannollinen lannan pinnan alaan, koska yllä esitetty emission lauseke on pinta-alayksikköä kohti. Siten mitä laajemmalle pinta-alalle lantaa on eläinsuojassa levinnyt, sitä enemmän siitä haihtuu ammoniakkia pitopaikan ilmaan. Raappojen käyttö lannanpoistossa maksimoi mallin mukaan ammoniakin emission.

Tutkimuksen tavoitteena on luoda helppokäyttöinen ja edullinen tapa valvoa eläinsuojien ilmanlaatua ja lämpötilaa eläinten parhaan mahdollisen hyvinvoinnin ja sitä kautta hyvän tuotannon ja tuotannon laadun edistämiseksi unohtamatta itse rakennuksen hyvinvointia rakennuksen pitkän ja terveen käyttöiän takaamiseksi. Tavoitteena on tutkia ja kehittää karjasuojien sisäilmaston laatua siten, että myös muut kaasut kuin hiilidioksidi ja vesihöyry (kosteus) on otettu huomioon ja että eläinten omat 'mukavuusrajat' on paremmin määritetty. Tämä toteutetaan mittausten lisäksi laskemalla lehmien lämpötasapaino ja mallintamalla ammoniakin ja muiden kaasujen kehittymistä ja vapautumista. Tämä lähtökohta selvittää olosuhteiden perusilmiöt, jolloin tietämys ilmiöistä paranee ja myös toimenpiteet osataan kohdistaa oikein. Osatavoitteet ovat tieteellisesti perustellut mikroilmastomalli ja lämpötasemalli sekä käytännön ohjeet mikroilmaston seurantaan ja ilmanvaihdon automatisointiin tarvittavista mittalaitteista. Lypsylehmien mukavuutta rajoittavia tekijöitä ovat Suomen talviolosuhteissa usein kaasupitoisuudet mutta joskus myös pöly ja mikrobit, kun ilmanvaihtoa rajoitetaan lämpötilan nostamiseksi. Kylmäkasvatusolosuhteissa ongelmaksi saattaa myös osoittautua kehon ääreisosien kuten hännän tai korvien jäätyminen, vaikka lämpötaseen mukaan ongelmaa ei vielä olisikaan. Kesälaitumella ongelmaksi saattaa muodostua lämpöstressi.

Nuorilla eläimillä on aikuisia vähemmän kehon rasvaa, ja niiden laskennalliset lämpötilan kriittiset alalämpötilat ovat huomattavasti korkeammat kuin aikuisilla naudoilla. Vasikoita kasvatetaan Suomessa enenevässä määrin igluissa, joissa mikroilmasto poikkeaa muusta karjasuojan ilmastosta. Lämpötasemalli kertoo, mitkä ovat suotuisat olosuhteet. Laskennallisten mallien etuina on, että niistä saadaan välittömästi suositus tilan omistajalle tai ilmanvaihdon säätöjärjestelmään, kun karjasuojan fysikaalisissa olosuhteissa (lämpötila, kosteus, ilmanlaatu) tapahtuu muutoksia. Muuttuneisiin olosuhteisiin voidaan reagoida muuttamalla esimerkiksi ilmanvaihtoa tai lämpötilaa. Lisäksi ilmanvaihto voidaan automatisoida tarkemmin kaasu- ja lämpötila-anturien mittauksilla sekä laskennallisen mallin antaman suosituksen perusteella kuin nykyiset lämpötilasäätimellä toimivat mallit, mikä saattaa näkyä kulujen säästöinä karjatilalla, kun eläinten olosuhteet suojassa pysyvät mahdollisimman tasaisina ja takaavat eläimen parhaan mahdollisen hyvinvoinnin.

\section{Mittaussysteemi}

Karjasuojan optimaalinen ilmasto saadaan aikaan oikealla ilmanvaihdolla. Tarvitaan automatisoitu tai hälytyksiä antava järjestelmä, jonka avulla karjasuojan optimiolosuhteet voidaan toteuttaa mahdollisimman stabiililla tavalla. Tarkoitusta varten tarvitaan puolestaan oikeita asioita mittaavat kohtuuhintaiset ja luotettavat anturit.

Kaasut ovat ainakin talviaikaan merkittävä ongelma navetoissa. Kriittinen kaasu näyttäisi useinkin olevan ammoniakki. Sikaloissa ilmanvaihdon saattaa puolestaan määrätä rikkivetypitoisuus, kanaloissa ongelmana voi olla ammoniakki. Pistemittauksin voidaan selvittää todennäköisimmät kaasut, joiden perusteella ilmanvaihto tulisi säätää. Aiemmin esimerkiksi. hiilidioksidi- ja kosteusanturit olivat melko kalliita, mutta nyt markkinoilla on muutaman kymmenen euron hintaisia antureita, joten hinta ei ole enää este kehitykselle.

Anturien antamaa tietoa voidaan käyttää ilmanvaihdon säätöön, jolloin vain yhden suureen säädöstä (lämpötila tai kosteus tai hiilidioksidi tai muu kaasu) voidaan siirtyä mallintamissäätöön, jossa voidaan käyttää useampaa suuretta samanaikaisesti ja sillä tavoin parantaa karjasuojien sisäilman 
laatua. Yksinkertaisempi vaihtoehto voisi olla hälytysjärjestelmä, jolloin säätö suoritettaisiin manuaalisesti.

Helsingin yliopiston Agroteknologian laitokselle on viime vuosina hankittu kattava mittauslaitteisto karjasuojien mikroilmaston sekä eläinten, työntekijöiden ja rakennusten hyvinvointiin liittyvien fysikaalisten parametrien mittaamiseksi. Kannettavalla kaasuspektrometrilla on mahdollista mitata lähes kaikkia navetan kaasuja rikkivetyä lukuun ottamatta. Jatkuvaan ammoniakin ja rikkivedyn mittaamiseen on hankittu omat laitteensa. Kosteus-, hiilidioksidi- ja lämpötilamittauksia varten on rakennettu omat anturoinnit, jonka etuna on kaupallisia versioita edullisempi hinta, jolloin antureiden lukumäärää mittauksissa voidaan kasvattaa. Runsaslukuisina hiilidioksidi- (tai muu kaasu), lämpötilaja kosteusanturit mahdollistavat navetan mikroilmaston täydellisen avaruudellisen kartoittamisen. Lämpökamera mahdollistaa eläimen säteilylämpötilajakauman mittaamisen. Lämpökameralla on helppo paikallistaa eläimen kriittiset alueet kuten korvat, utareet tai häntä, kuva 1.

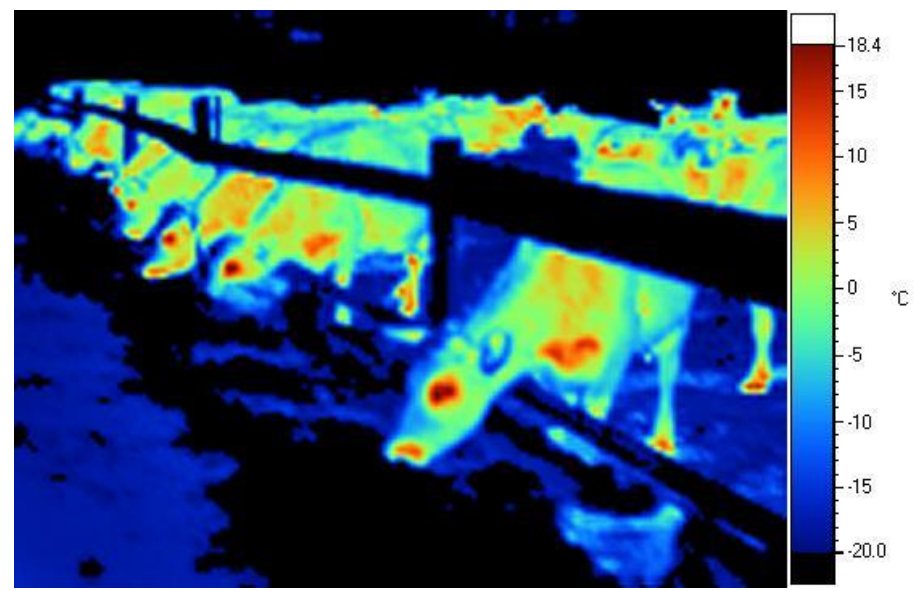

Kuva 1. Lämpökamerakuva navetasta, kun ulkolämpötila oli -40 C.

Laitokselle hankittiin äskettäin myös pölymittari ilmassa olevan hiukkasjakauman mittaamiseen. Ennen ostopäätöstä laite testattiin navetan haastavissa olosuhteissa testaamalla heinien pöyhimisen ja jauholaarin sekoittamisen vaikutus mittaustuloksiin, minkä jälkeen laitevalmistaja tarkisti laitteen.

Ilman mikrobipitoisuuden mittaamiseen käytetään MAS- mikrobikeräintä, jonka avulla voidaan määrittää ilman home- ja bakteeripitoisuudet. Laitetta on aiemmin käytetty Agroteknologian laitoksella muun muassa ulkoilman mikrobipitoisuuksien mittaamiseen (32) sekä lämmöneristetutkimuksissa $(33,34)$. Laite soveltuu hyvin myös navettaympäristöön, mikä on todettu laitoksen opetuksessa.

Mittauslaitteistot ovat tällä hetkellä käytössä usealla tilalla. Anturit on kytketty tiedonkeruulaitteistoon, joka lähettää mittaustulokset automaattisesti verkkosivulle (on line) mistä tahansa karjasuojasta Suomessa GSM-verkon kautta tietokantapalvelimelle.

\section{Tuloksia}

Kuvissa 2 - 3 on puolen tunnin välin suoritetut CO2-mittaukset vuoden ajalta kahdesta erilaisesta navetasta. Kuvista nähdään merkittävät erot pitoisuuksissa. Talvella on suuri houkutus pienentää ilmanvaihtoa, jonka seurauksena pitoisuudet voivat nousta liian korkeiksi. Toisaalta eristetty katto auttaa kesällä pitämään lämpötilan alhaisempana kuin eristämättömässä rakennuksessa.

Eristämättömässä lämpötila seuraa kesällä aika tarkasti ulkolämpötilaa. Runsastuottoisilla lehmillä ainoa mahdollinen ongelma on siis ilmanvaihdon riittämättämyys sen takia, että työntekijä haluaa itselleen miellyttävät olosuhteet. Tämä aiheuttaa ongelmia rakennuksen terveydelle, kun suhteellinen kosteus nousee korkeaksi mahdollistaen esim. lahoamisen. Tarvitaan siis kompromissi.

Tällä hetkellä automaattiset mittaussysteemit ovat myös sikalassa, kanalassa ja broilerkasvattamossa. Alustavat mittaukset viittaavat siihen, että suurimmat ongelmat näissä rakennuksissa saattavat koskea pöly- ja mikrobipitoisuuksia. Ilmanvaihto on näissä useinkin automatisoitu lämpötilan ja kosteuden avulla, joten ne ovat kohdallaan. 


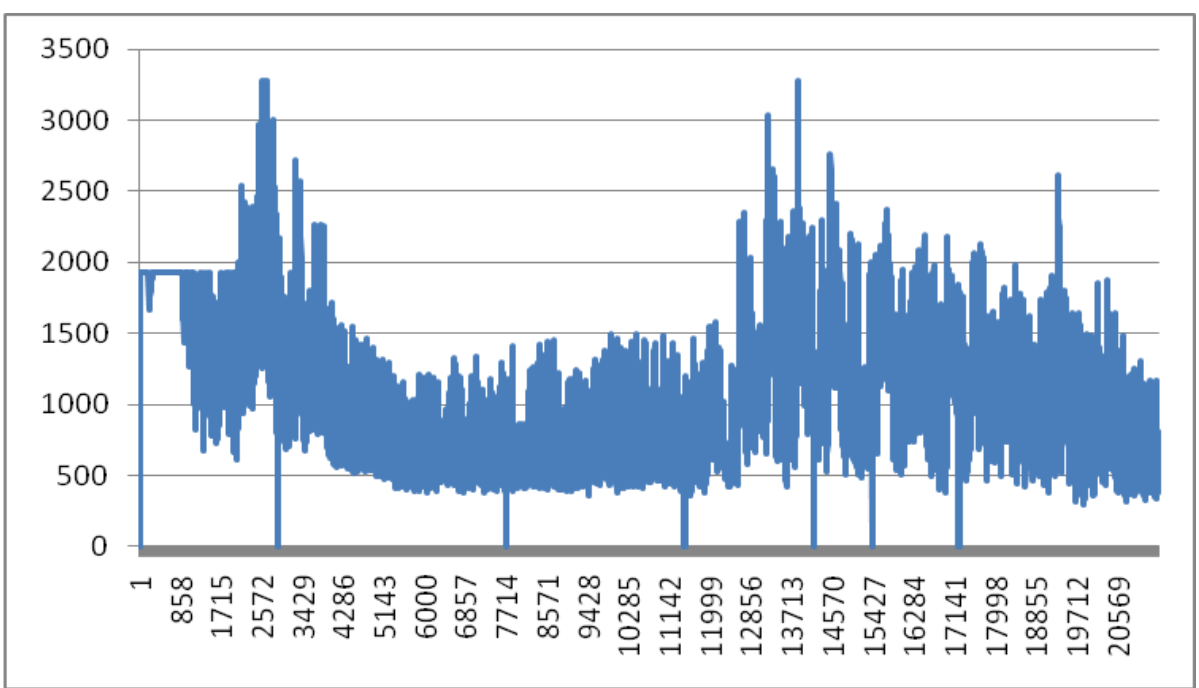

Kuva 2. Puolieristetty pihatto: katto eristetty, verhoseinät. Janakkala.

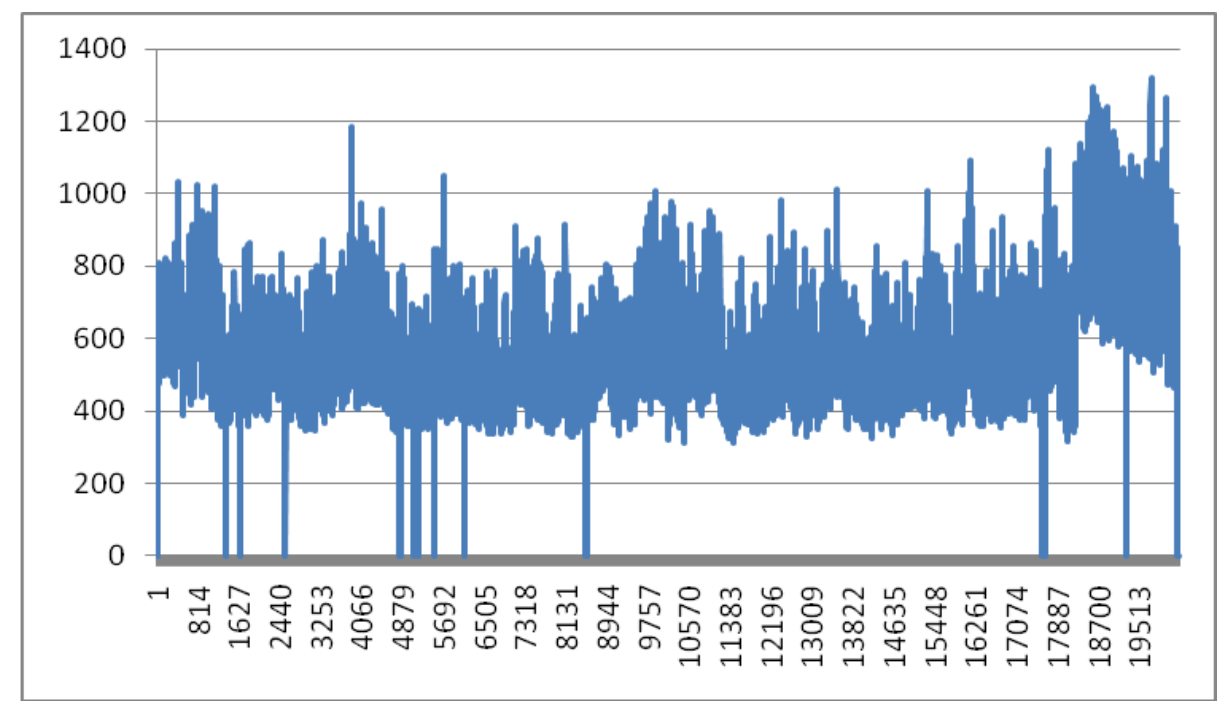

Kuva 3. Eristämätön, seinät harvaa laudoitusta. Iitti.

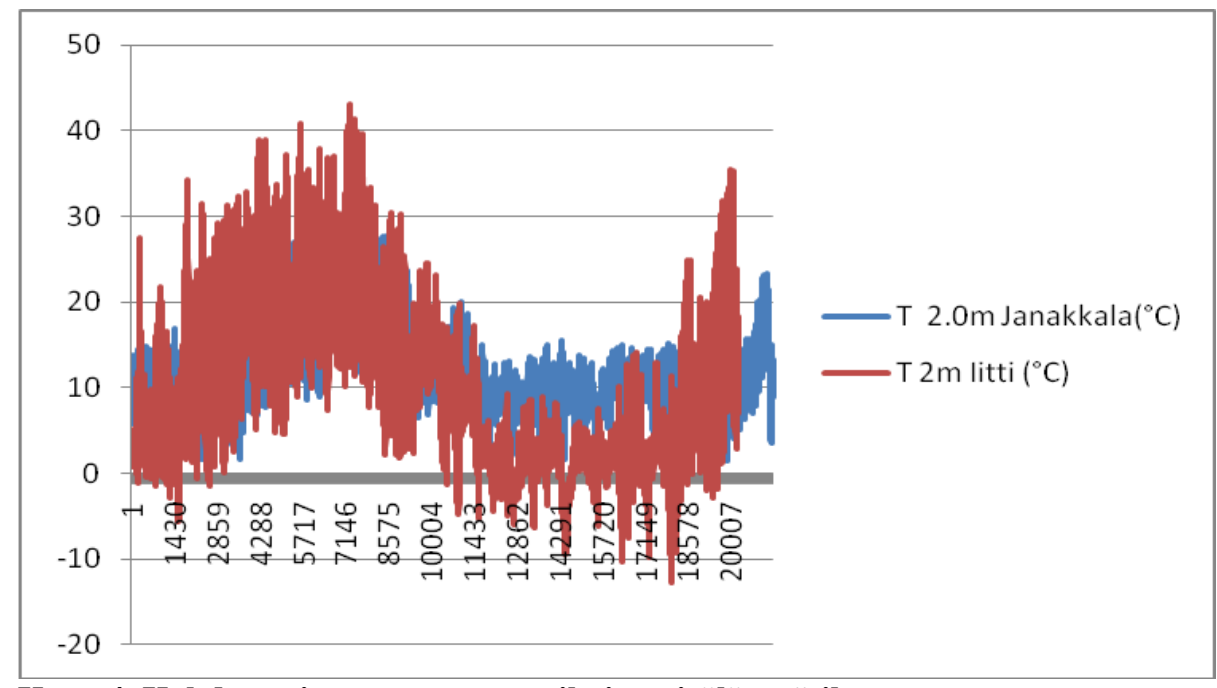

Kuva 4. Kahden eri navetan samanaikaiset sisälämpötilat 


\section{Johtopäätökset}

Uudet mittausjärjestelmät antavat jatkuvaa tietoa karjasuojien olosuhteista. Mittauksissa näkyy hyvin vuorokautiset ja vuoden aikojen mukaiset vaihelut. Mittausantureiden ja -järjestelmien hinnat ovat alentuneet viime vuosina runsaasti ja sen seurauksena karjasuojissa tullaan siirtymään tulevaisuudessa tarkempiin säätöjärjestelmiin, joiden avulla voidaan taata eläimille hyvät olosuhteet ja ilmanvaihto voidaan aina mukauttaa vallitsevaan tilanteeseen (säähän).

\section{Kirjallisuusluettelo}

1. Ruunaniemi J., Hautala M. \& Ahokas J. Physical Properties of Synthetic Bedding Materials for FreeStall Dairy Cow. Agricultural and Food Science 14 (2005) 134-142.

2. Pastell M., Takko H., Gröhn H., Hautala M., Poikalainen V., Praks J., Veermäe I., Kujala M. \& Ahokas J. Measuring Cow's Welfare: Weighing the Cow in a Milking Robot. Biosystems Engineering (2006) 93 (1), 81-87.

3. M. Pastell, A-M. Aisla, M. Hautala,V. Poikalainen, J. Praks, I. Veermäe and J. Ahokas, Contactless Measurement of Cow Behavior in a Milking Robot, Behavior Research Methods, 38 (2006) 479-483.

4. Pastell M., Hautala M., Poikalainen V., Praks J., Veermäe I., Kujala M. \& Ahokas J. Automatic observation of cow's leg health using load sensors. Computers and Electronics in Agriculture. 62 (2008) 48-53.

5. Pastell, Matti, Kujala, M., Aisla, A. M., Hautala, Mikko, Poikalainen, V., Praks, J., Veermäe, I., Ahokas, Jukka, Detecting cow's lameness using force sensors, Computers and electronics in agriculture 64 (2008) : 1, s. 34-38.

6. Hautala M., Ahokas J. \& Ruunaniemi J. Heat Transfer from Cow to Floor: Theory and Experiment. International Conference of Agricultural Machinery, Building and Energy Engineering. Estonian Agricultural University Transactions 214. Tarto 2001, p. $64-69$.

7. Hautala M., Ahokas J., Ruunaniemi J., Manninen E. and Saloniemi H. Heat Transfer from Cow to Floor: Theory and Experiment. AgEng 2002 - Conference, Budapest 2002 (02-AP-016)

8. Ahokas J., Hautala M., Poikalainen V., Praks J. \& Veermäe I. Lehmän terveyden mittaaminen automaattilypsyn yhteydessä. Suomen Maataloustieteellinen Seura, Maataloustieteen päivät 2004. http://www.agronet.fi/maataloustieteellinenseura/julkaisut/posterit04/kh10.pdf

9. Ahokas J., Pastell M., Takko H., Hautala M., Poikalainen V., Praks J. \& Veermäe I. Measuring cow’s welfare: Weighing the cow in a milking robot. AgEng 2004 Conference, 12-16.9.2004, Leuven, Belgium.

10. Ahokas J., Pastell M., Takko H., Hautala M., Poikalainen V., Praks J. \& Veermäe I. Measuring cow's welfare: Weighing the cow in a milking robot. Smart 2004 Workshop, Third International Workshop on Smart Sensors in Livestock Monitoring, 10 -11.9 2004, Leuven, Belgium.

11. Ruunaniemi J. Ahokas \& Hautala M. Physical properties of free-stall dairy cow synthetic beds and mats. AgEng 2004 Conference, 12-16.9 2004, Leuven, Belgium

12. Poikalainen V., Ahokas J., Praks J., Hautala M., Aland A. \& Veermäe I. Automatic Measurement System for Cow Leg Disorder Determination. International Society for Animal Hygiene, International congress at Saint-Malo - FRANCE, 11 - 13.102004

13. Pastell M., Takko H., Hautala M., Poikalainen V., Veermäe I. \& Ahokas J. Monitoring cow health in a milking robot. Precision Livestock Farming '05, Wageningen Academic Publishers, 2005. p. 187 - 192

14. Poikalainen V., Veermae I., Praks J., Aland A., Kokin E., Laikoja K., Ahokas J. \& Hautala M. Posssibilities of Automatic Assessment of Cows Welfare. ISAH 2005 XII $^{\text {th }}$ International Congress Warsaw 2005. Proceedings, Volume 1, p 180 - 183.

15. Pastell M., Aisla A-M., Hautala M., Ahokas J., Poikalainen V., Praks J. \& Veermäe I. Automatic Cow Health Measurement System in a Milking Robot. ASABE Meeting Presentation, Paper Number: 064037. American Society of Agricultural and Biological Engineers, Annual Meeting 2006. 8 p.

16. Pastell M., Aisla A-M., Hautala M., Poikalainen V., Praks J. \& Ahokas J. Measuring Lameness in Dairy Cattle Using Force Sensors. World Congress: Agricultural Engineering for a Better World. CIGR, EurAgEng, VDI, FAO World Congress Bonn 2006. VDI Verlag Dusseldorf 2006. 5 p.

17. Kaihilahti J., Pastell M., Huhtala A., Aisla A-M. , Teye F., Hautala M., Vainio O., Lensink J. \& Ahokas J. New Monitoring Methods of Dairy Cattle Welfare in Finland. World Congress: Agricultural Engineering for a Better World. CIGR, EurAgEng, VDI, FAO World Congress Bonn 2006. VDI Verlag Dusseldorf 2006. 5 p.

18. Pastell M., Oliviero C., Hautala M., Ahokas J., Peltoniemi O., Vainio O. Automatic Detection of Farrowing. Smart 2006, Fourth International Workshop on Smart Sensors in Livestock Monitoring. Gargnano, Italy 2006, p. $17-18$. 
19. Pastell M., Aisla A-M., Hautala M., Poikalainen V., Praks J. Veermäe I., Ahokas J. Detecting Cow's Lameness in a Milking Robot. Smart 2006, Fourth International Workshop on Smart Sensors in Livestock Monitoring. Gargnano, Italy 2006, p. 25 - 26.

20. Pastell, Matti, Kaihilahti, J., Aisla, Anna-Maija, Hautala, Mikko, Poikalainen, V., Ahokas, Jukka, A system for contact-free measurement of respiration rate of dairy cows, Precision livestock farming '07, Wageningen, 2007, s. 105-109.

21. Frederick K. Teye and Mikko Hautala, Measuring ventilation rates in dairy buildings, Journal of Ventilation, 6 (2007) 247-256.

22. F.K. Teye, Huatala M., Pastell M., Praks J., Veermäe I., Poikalainen V., Pajumägi A., Kivinen T. and Ahokas J. Microclimate and ventilation in Estonian and Finnish dairy buildings, Energy and buildings, $40(2008): 7$.

23. M. Hautala and F. K. Teye, Adaptation of ammonia volatilazation model for naturally ventilated dairy buildings, Atmospheric Environment, 42 (2008) : 18, s. 4345-4354.

24. Teye F., Gröhn H., Pastell M., Hautala M., Pajumägi A., Praks J., Poikalainen V., Kivinen T. \& Ahokas J. Microclimate and gas emissions in cold uninsulated dairy buildings. ASABE Meeting Presentation, Paper Number: 064080. American Society of Agricultural and Biological Engineers, Annual Meeting 2006. 8 p.

25. Teye F., Gröhn H., Pastell M., Hautala M., Poikalainen V., Pajumägi A., Praks J., Mattila K., Kivinen T. \& Ahokas J. Gaseous emissions in cold uninsulated dairy buildings. World Congress: Agricultural Engineering for a Better World. CIGR, EurAgEng, VDI, FAO World Congress Bonn 2006. VDI Verlag Dusseldorf 2006. 6 p.

26. Poikalainen V., Veermäe I., Praks J., Kaart T., Kokin E., Pastell M., Ahokas J. \& Hautala M. Remote monitoring and analysis of indoor temperature, dairy cow's health and productivity in large loosehousing cowsheds by an automatic network system. XII International Congress in Animal Hygiene, ISAH-2007 Tartu, Estonia. p. 604-609.

27. Teye F., Hautala M., Pastell M., Veermäe I., Poikalainen V., Pajumägi A., Kivinen T \& Ahokas J. Microclimate in cowsheds in Finland and Estonia. XII International Congress in Animal Hygiene, ISAH-2007 Tartu, Estonia. p. 83-88.

28. Hautala M, NH3 emission from manure: physicist's view. Ammonia emissions in Agriculture, Wageningen, 2007, p. 277-278.

29. Kokin, E. Veermäe, I., Poikalainen, V., Praks, J., Pastell, Matti, Ahokas, Jukka, Hautala, Mikko, Environment, health and welfare monitoring in precision livestock farming of dairy cattle, Precision livestock farming '07, Wageningen, 2007, s. 171-177.

30. Kivinen, Tapani, Ahokas, Jukka, Poikalainen, Väinö, Teye, Frederick, Hautala, Mikko, Tamminen, Petro, Veermäe, Imbi, Pajumägi, Aime, Kylmäpihattojen toimivuus Suomessa ja Virossa , 2008, 63 s., MTT:n selvityksiä, ISSN 1458-509X ; 155.

31. Hautala, Mikko, Mäkelä, Matti, Pastell, Matti, Raussi, Satu, Hänninen, Laura, Saloniemi, Hannu, Upper and lower critical temperatures for cattle , AgEng2008 International conference on agricultural engineering, : conference proceedings CD. - Athens : AgEng2008 P-146, 9 s..

32. Koivula, M.J., Kymäläinen, H.-R., Virta, J., Hakkarainen, H., Hussein, T., Komulainen, J., Koponen, H., Hautala, M., Hämeri, K., Kanerva, P., Pehkonen, A. \& Sjöberg, A.-M. 2005. Emissions from thermal insulations - part 2: evaluation of emissions from organic and inorganic insulations. Building and Environment 40, 803-814.

33. Virta, J., Koivula, M.J., Hussein, T., Koponen, S., Hakkarainen, H., Kymäläinen, H.-R., Hämeri, K., Kulmala, M. \& Hautala, M. 2005. Emissions from thermal insulations - part 1: development and characteristics of the test apparatus. Building and Environment 40, 797-802.

34. Koivula, M.J., Kymäläinen, H.-R., Vanne, L., Levo, S., Pehkonen, A. \& Sjöberg, A.-M. 2004. Microbiological quality of linseed and fibre hemp plants during growing and harvesting seasons. Agricultural and Food Science 13, 4: 327-337. 